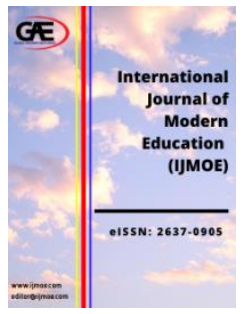

\author{
INTERNATIONAL JOURNAL OF \\ MODERN EDUCATION \\ (IJMOE) \\ wWw.ijmoe.com
}

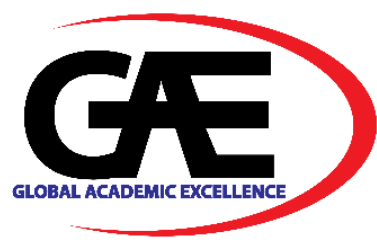

\title{
EFFECTIVENESS OF LEARNING THROUGH VIDEO CLIPS AND VIDEO LEARNING IMPROVEMENTS BETWEEN BUSINESS RELATED POSTGRADUATE AND UNDERGRADUATE STUDENTS
}

Dominic Wong $^{1 *}$

1 Faculty of Accountancy, Finance \& Business, Tunku Abdul Rahman University College (TARUC), Malaysia Email: wonght@tarc.edu.my

* Corresponding Author

Article Info:

Article history:

Received date: 01.11.2020

Revised date: 15.11 .2020

Accepted date: 30.11 .2020

Published date: 08.12.2020

To cite this document:

Wong, D. (2020). Effectiveness Of Learning Through Video Clips And Video Learning Improvements Between Business Related Postgraduate And Undergraduate Students. International Journal of Modern Education, 2(7), 119-127.

DOI: $10.35631 /$ IJMOE.27009

This work is licensed under $\mathrm{CC}$ BY 4.0

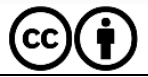

Abstract:

Learning is important for students to build their foundation of knowledge that they can utilize in their future careers. Learning through videos is considered an effective tool for many students, the topic was well-reviewed by many researchers. This paper is going to explore the learning effectiveness of video in teaching business-related topics and will also include suggestions to improve teaching using video clips. The researcher is using Google Form survey as the main tool for data collection, simple descriptive statistics and T-Tests are used in this research. Indeed, the results show that learning through video is perceived as effective by students. A simple comparison between postgraduate and undergraduate students' perceptions towards the learning effectiveness and improvements is also conducted in which they are indifferent in most variables.

Keywords:

Video Learning, Effectiveness, Business Students

\section{Introduction}

Learning is important for students to build a foundation of knowledge they can utilize in their future careers. Learning via videos is considered an effective tool for many students, as the topic was well reviewed by many researchers. Kay (2012) discovered that videos are indeed good for improving students' learning ability. Apart from Kay, other studies have also revealed 
that videos are good for supporting students in learning (Ljubojevic, Vaskovic, Stankovic and Vaskovic, 2014 ; Hsin \& Cigas, 2013).

This purpose of this paper is to explore the learning effectiveness of using videos in teaching business related topics and include suggestions to improve teaching using video and clips. A comparison is also done to observe the difference in perceptions of learning effectiveness and improvements between business related postgraduate and undergraduate students. As mentioned by Illovsky (2010), in his study, he found out the differences in traits between postgraduate and undergraduate students. The researcher is using Google Form surveys as the main tool for data collection. Simple descriptive statistics and T-Tests are used in this research.

\section{Literature Review}

Based on the study by Ljubojevic et al. (2014), students performed better when videos were included in the mid-session of the lecture. López, Ferrando and Fabregat-Sanjuan (2016) also found out that students found the videos and clips to be the most useful and efficient teaching tool to improve learning. Brecht (2012) found out that videos and clips designed to support tutoring have a significant result. In addition, Geri (2012) indicated about $94 \%$ of the students might improve their understanding of the learning materials via watching videos.

Besides, video lectures seem to be a good tool to enhance distance learning, as Geri (2012) found out that students who failed would still continue their studies after an introduction to video materials. In another study, Copley (2007) mentioned that video lectures might reduce loneliness and increase the attention span of the distance learners.

It seems, the inclusion of videos in learning is also beneficial in tests or examinations (Beheshti, Taspolat, Kaya \& Sapanca, 2018). Ljubojevic et al. (2014) conducted a research based on the inclusion of videos and clips into lectures and impacts on students' test results. It seemed that it did affect the results in a positive way. In another setting by Hsin and Cigas (2013), they also found out that more students passed the course after having videos as part of the course. In another study, students responded that the summary videos produced were useful for their exam revisions (Whatley \& Ahmad, 2007). An encouraging result was found by Brecht \& Ogilby (2008), failed grades were reduced by $72 \%$ after the learning videos were available.

Kay (2012) did a thorough research on learning effectiveness through videos. She found out that video-based learning did bring benefits in understanding, motivation in learning, improving study habits and better grades. In a nutshell, the inclusion of videos and clips in learning have positive learning outcomes.

Brame, the assistant director of Center for Teaching in Vanderbilt University (2016) stipulated that in order to create effective video-based learning, she listed out a few suggestions to improve video-based learning. These were her suggestions;

1. Displaying key information (signalling).

2. Segmenting the video clip into smaller pieces (segmenting)

3. Elimination of extraneous information (weeding)

4. Matching the process of both audio and visual channel to convey information (matching modality)

5. Making materials that are relevant for a particular class. 
In addition, Bell and Bull (2010) also mentioned that teachers need to actively participate in controlling the video session such as pausing, asking questions, replaying key segments and assessing understanding. If teachers were not around to control of the video and clips, the students' understanding of the videos may be hampered (Bell \& Bull, 2010).

In another research by Zhang, Zhou, Brigss and Nunamaker (2006), they found out that videos do play a role in the satisfaction level of learners towards e-learning. In a nutshell, as the few studies indicated above have already identified the effectiveness of learning via video, the rest of this paper is going to explore the learning effectiveness of videos in teaching business related topics and will also include suggestions to improve teaching using videos and clips.

For the comparison between business student degree levels, Illovsky (2010) found out that postgraduate students were more concerned about achievement, avoiding harm, and understanding their levels and self-positivity if compared to the undergraduates. Endurance also seems more important at postgraduate level even it was not significant (Illovsky, 2010). Similarly, postgraduate students seemed more studious, more expressive and more interactive when dealing with tutors (Peixoto, Peixoto \& Alves, 2012). In another study in Malaysia, postgraduate students once again were more tech savvy in basic computer hardware (i.e. computer, printers, mouse etc.) \& software (i.e. office applications such as Word Processor) and more independent (Adams, Sumintono, Mohamed \& Mohamad Noor, 2018). Besides, Lau, Chiu, Ho, Lo and See-To (2017), found out that undergraduates and postgraduates were mostly indifferent in learning via mobile devices, however postgraduates are marginally higher in accessing materials via mobile devices. Conway (2012) further discovered that postgraduate students did have a marginal higher performance in understanding assignment materials and better information searching skills. All in all, from all these studies listed above, postgraduate students seemed more hard working, more persistent and had better learning skills. It's worth noting that most studies as above were focused on differences in traits or characteristics, and no previous research is done in the comparing the video learning effectiveness between postgraduate and undergraduate students. Perhaps, the closest in this case was the study Adams et al. (2018) in gauging mobile learning difference between postgraduate and undergraduate students. Therefore, if this leads one of the research objectives as above, will the postgraduate students display different perceptions in video learning?

\section{Research Methodologies}

The researcher is conducting this research via questionnaire. In particular, Google Form will be used as the main tool in soliciting answers from students. Students can answer anytime and anywhere as Google Form can be accessed in any Internet browser such as Chrome and Safari via mobile devices or desktop computers. However, for this paper, the researcher is only focusing on learning effectiveness and improvement. Questions are focused on learning effectiveness such and videos can explain a concept easily, to make it easier for students to understand and that video learning is more interesting. Whereas, the learning improvement questions are mostly gathered from a literature review especially from Brame (2016), improvement questions for instance are displaying key information and segmenting the video into smaller parts.

Respondents are different groups of business students in university or colleges, and may come from diverse business streams such as accounting, business management, entrepreneurship, human resource, marketing etc. The researcher is currently utilising video clips in most lectures 
(i.e. once or twice per lecture), video clips are usually played in the middle of the lecture sessions or when certain concepts need to be explained. Hence, this paper is served as an explorative research to gauge basic effectiveness of video learning based on utilising videos in teaching and therefore the sample is still small, but the researcher intends to collect more than 30 responses from students. Respondents are solicited from the university that the researcher is currently working i.e. Tunku Abdul University College.

For the current paper, the researcher is going to analyse the learning effectiveness of video learning using descriptive statistics such as mean and percentage. The improvement section of the video learning is also included, and all variables in improvement section are based on the perception levels of learners. The researcher is further categorising the learning effectiveness based on different degree levels, in this aspect, the researcher is using T-Test analysis to check the significant difference between postgraduate and undergraduate students (Sekaran \& Bougie. 2016).

\section{Findings}

\section{Demographics Analysis}

Based on the Google Form's response page, the researcher collected 53 responses from students. Refer to Table 1, respondents are mostly female with $62.26 \%(n=33)$ and $37.74 \%$ male $(n=20)$. All respondents are young adults below 31 years old in which percentage of students below 26 years old is $98.11 \%$. Forty four $(83.02 \%)$ of respondents are currently studying bachelor degrees and while only $9(16.98 \%)$ are studying master degrees.

Table 1: Demographics Of Respondents

\begin{tabular}{|l|l|l|l|}
\hline & Details & Number & $\%$ \\
\hline Gender & Male & 20 & 37.74 \\
\hline & Female & 33 & 62.26 \\
\hline Age Groups & $18-20$ & 20 & 37.74 \\
\hline & $21-25$ & 32 & 60.38 \\
\hline & $26-30$ & 1 & 1.89 \\
\hline Degree Level & Bachelor & 44 & 83.02 \\
\hline & Master & 9 & 16.98 \\
\hline
\end{tabular}

\section{Overall Learning Effectiveness Analysis}

From Table 2, video clips seemed good enough to explain topic/concepts to students, and a vast majority of students (about $68 \%, \mathrm{n}=36$ ) agree on this matter with a mean score of 3.85 . Similarly, video clips are great in helping the students to understand the topic/concept, and again the mean score is 3.83 and nearly $68 \%$ of students agree on video clips enhance their understanding. Learning via videos also makes the topic more interesting, and about $77 \%$ of students agree on this with a mean score nearing to 4 (3.96). While it seems to be the lowest mean score for video clips enriches the topic that lecturer is teaching, this variable is still near to 3.8 with nearly $70 \%$ of students agree on this matter. Last but not least, students think positively that videos and clips can link to relevant topics that the lecturer taught with a mean score of 3.81 and again about $68 \%$ of students agreed on this benefit. 
Volume 2 Issue 7 (December 2020) PP. 119-127 DOI: 10.35631/IJMOE.27009

Table 2: Video Learning Effectiveness

\begin{tabular}{|c|c|c|c|c|c|c|c|c|c|c|c|c|}
\hline \multirow[t]{2}{*}{ Variable } & \multicolumn{2}{|c|}{$\begin{array}{c}\text { Strongly } \\
\text { Disagree } \\
\text { (1) }\end{array}$} & \multicolumn{2}{|c|}{$\begin{array}{l}\text { Disagree } \\
\text { (2) }\end{array}$} & \multicolumn{2}{|c|}{$\begin{array}{l}\text { Moderate } \\
\text { (3) }\end{array}$} & \multicolumn{2}{|c|}{$\begin{array}{l}\text { Agree } \\
\text { (4) }\end{array}$} & \multicolumn{2}{|c|}{$\begin{array}{l}\text { Strongly } \\
\text { Agree (5) }\end{array}$} & \multirow[t]{2}{*}{$\begin{array}{l}\text { Std. } \\
\text { Dev }\end{array}$} & \multirow[t]{2}{*}{ Mean } \\
\hline & No & $\%$ & No & $\%$ & No & $\%$ & No. & $\%$ & No & $\%$ & & \\
\hline $\begin{array}{l}\text { Explain A } \\
\text { Topic/Concept }\end{array}$ & 0 & 0.00 & 3 & 5.66 & 14 & 26.42 & 24 & 45.28 & 12 & 22.64 & 0.84 & 3.85 \\
\hline $\begin{array}{l}\text { Understand The } \\
\text { Topic/Concept }\end{array}$ & 0 & 0.00 & 4 & 7.55 & 13 & 24.53 & 24 & 45.28 & 12 & 22.64 & 0.87 & 3.83 \\
\hline $\begin{array}{l}\text { Makes The } \\
\text { Topic/Concept } \\
\text { More Interesting }\end{array}$ & 0 & 0.00 & 3 & 5.66 & 9 & 16.98 & 28 & 52.83 & 13 & 24.53 & 0.81 & 3.96 \\
\hline $\begin{array}{l}\text { Enhances/Enrich } \\
\text { es The Topic } \\
\text { That The } \\
\text { Lecturer Taught }\end{array}$ & 0 & 0.00 & 3 & 5.66 & 13 & 24.53 & 29 & 54.72 & 8 & 15.09 & 0.77 & 3.79 \\
\hline $\begin{array}{l}\text { Think About } \\
\text { Related Issues Of } \\
\text { The Topic That } \\
\text { The Lecturer } \\
\text { Taught }\end{array}$ & 0 & 0.00 & 2 & 3.77 & 15 & 28.3 & 27 & 50.94 & 9 & 16.98 & 0.76 & 3.81 \\
\hline
\end{tabular}

\section{Overall Improvement Analysis}

Table 3: Improvements On Video Learning

\begin{tabular}{|c|c|c|c|c|c|c|c|c|c|c|c|c|}
\hline \multirow[t]{2}{*}{ Variable } & \multicolumn{2}{|c|}{$\begin{array}{l}\text { Strongly } \\
\text { Disagree } \\
\text { (1) }\end{array}$} & \multicolumn{2}{|c|}{$\begin{array}{c}\text { Disagree } \\
\text { (2) }\end{array}$} & \multicolumn{2}{|c|}{$\begin{array}{l}\text { Moderate } \\
\text { (3) }\end{array}$} & \multicolumn{2}{|c|}{$\begin{array}{c}\text { Agree } \\
\text { (4) }\end{array}$} & \multicolumn{2}{|c|}{$\begin{array}{l}\text { Strongly } \\
\text { Agree (5) }\end{array}$} & \multirow[t]{2}{*}{$\begin{array}{l}\text { Std. } \\
\text { Dev }\end{array}$} & \multirow[t]{2}{*}{ Mean } \\
\hline & No. & $\%$ & No. & $\%$ & No. & $\%$ & No. & $\%$ & No. & $\%$ & & \\
\hline $\begin{array}{l}\text { Display key } \\
\text { information }\end{array}$ & 0 & 0.00 & 0 & 0.00 & 8 & 15.09 & 26 & 49.06 & 19 & 35.85 & 0.69 & 4.21 \\
\hline $\begin{array}{l}\text { Segmenting the } \\
\text { video clips into } \\
\text { small parts }\end{array}$ & 1 & 1.89 & 0 & 0.00 & 11 & 20.75 & 25 & 47.17 & 16 & 30.19 & 0.83 & 4.04 \\
\hline $\begin{array}{l}\text { Eliminate of } \\
\text { extra } \\
\text { information }\end{array}$ & 0 & 0.00 & 3 & 5.66 & 16 & 30.19 & 17 & 32.08 & 17 & 32.08 & 0.93 & 3.91 \\
\hline $\begin{array}{l}\text { Video should } \\
\text { use proper } \\
\text { audio channel } \\
\text { (i.e. sound) that } \\
\text { is relevant to } \\
\text { the topic }\end{array}$ & 0 & 0.00 & 1 & 1.89 & 14 & 26.42 & 20 & 37.74 & 18 & 33.96 & 0.83 & 4.04 \\
\hline $\begin{array}{l}\text { Video should } \\
\text { use proper } \\
\text { visual channel } \\
\text { (i.e. picture or }\end{array}$ & 0 & 0.00 & 0 & 0.00 & 10 & 18.87 & 22 & 41.51 & 21 & 39.62 & 0.74 & 4.21 \\
\hline
\end{tabular}




\begin{tabular}{|l|l|l|l|l|l|l|l|l|l|l|l|l|}
\hline $\begin{array}{l}\text { image) that is } \\
\text { relevant to the } \\
\text { topic }\end{array}$ & & & & & & & & & & & & \\
\hline $\begin{array}{l}\text { Video should } \\
\text { be displayed } \\
\text { during middle } \\
\text { of a class } \\
\text { session }\end{array}$ & 0 & 0.00 & 4 & 7.55 & 11 & 20.75 & 25 & 47.17 & 13 & 24.53 & 0.87 & 3.89 \\
\hline
\end{tabular}

Improvements on video learning are presented in Table 3, all variables in the improvement section are based on the perception levels of learners. Video and clips should display key information to students, and a high percentage of students (about 85\%) agree on this matter with a mean score of 4.21 . Besides, video clips should be segmented to help the students to understand topic/concept better, about $77 \%$ of students agree on this (Mean=4.04). In order to make learning more effective, students also agree that videos should eliminate any irrelevant information (Agree $\%=64.16$, Mean=3.91). The next variables are that videos should use proper audio (i.e. sound) and visuals (i.e. image) that are relevant to the topic, both variables' mean scores are above 4 (Audio Mean =4.04; Visual Mean =4.21). Lastly, students think positively about video clips should be displayed during middle of a class session with mean score of 3.89 and about $72 \%$ of students agree on this matter.

\section{Comparison of Degree Level Analysis}

Table 4: Comparison of Video Learning Effectiveness

\begin{tabular}{|l|c|c|c|}
\hline Variables & $\begin{array}{c}\text { Undergraduate } \\
\text { (Bachelor) }\end{array}$ & $\begin{array}{c}\text { Postgraduate } \\
\text { (Master) }\end{array}$ & P value \\
\hline Explain A Topic/Concept & 3.75 & 4.33 & $0.045^{*}$ \\
\hline Understand The Topic/Concept & 3.80 & 4.00 & 0.504 \\
\hline $\begin{array}{l}\text { Makes The Topic/Concept } \\
\text { More Interesting }\end{array}$ & 3.98 & 3.89 & 0.756 \\
\hline $\begin{array}{l}\text { Enhances/Enriches The Topic } \\
\text { That The Lecturer Taught }\end{array}$ & 3.75 & 4.00 & 0.354 \\
\hline $\begin{array}{l}\text { Think About Related Issues Of } \\
\text { The Topic That The Lecturer } \\
\text { Taught }\end{array}$ & 3.80 & 3.89 & 0.727 \\
\hline
\end{tabular}

There is only one variable (i.e. video can explain a topic/concept) in which postgraduate students perceived significantly higher than undergraduate students (Postgraduate mean $=4.33$ and Undergraduate mean $=3.75, \mathrm{p}$ value $=0.045$ ). There rest of the variables show the indifference between the undergraduate and postgraduate students. Both groups agree on the effectiveness of learning through video and clips, and all variables are near to 4 which is the agreed level. 
Volume 2 Issue 7 (December 2020) PP. 119-127

Table 5: Comparison of Video Learning Improvements

\begin{tabular}{|l|c|c|c|}
\hline Variable & $\begin{array}{c}\text { Undergraduate } \\
\text { (Bachelor) }\end{array}$ & $\begin{array}{c}\text { Postgraduate } \\
\text { (Master) }\end{array}$ & P value \\
\hline Display key information & 4.23 & 4.11 & 0.632 \\
\hline $\begin{array}{l}\text { Segmenting the video clips into } \\
\text { small parts }\end{array}$ & 4.16 & 3.44 & $0.012^{*}$ \\
\hline Eliminate of extra information & 3.91 & 3.89 & 0.95 \\
\hline $\begin{array}{l}\text { Video should use proper audio } \\
\text { channel (i.e. sound) that is } \\
\text { relevant to the topic }\end{array}$ & 4.02 & 4.11 & 0.763 \\
\hline $\begin{array}{l}\text { Video should use proper visual } \\
\text { channel (i.e. picture or image) } \\
\text { that is relevant to the topic }\end{array}$ & 4.23 & 4.11 & 0.657 \\
\hline $\begin{array}{l}\text { Video should be displayed } \\
\text { during middle of a class session }\end{array}$ & 4.02 & 3.22 & $0.007^{*}$ \\
\hline
\end{tabular}

Similar to the effectiveness variables, both groups show indifference in the agreement level of improvements in most variables. However, there are two variables that show significant differences. Postgraduate students only perceive moderately about segmenting the videos and clips in smaller parts, and the other variable in which postgraduate students also feel moderately that videos should be displayed in the middle of the class session, whereas their undergraduate counterparts agree on these two variables. Results for these variables as follows:

- Segmenting the variable (Postgraduate mean=3.44 and Undergraduate mean=4.16, $p$ value $=0.012$ )

- Displaying video middle of the class (Postgraduate mean=3.22 and Undergraduate mean $=4.02$, $p$ value $=0.007$ ).

For effectiveness of video learning comparison, based on Illovsky's study (2010), since postgraduates are more concerned about understanding, therefore, it resonates with the postgraduate profile that explanation of a topic through video playing is more important for them.

Lastly, regarding improvements in video learning comparison, based on studies of Illovsky (2010), Peixoto et al. (2012), since postgraduates are more positive and they can endure slightly more difficulties, videos playing in the midst of the class and segmenting the video clips into smaller parts are not their main concern. Even though it's not totally related, Conway (2012) did mention that postgraduate students have better understanding skills in assignment materials, and it may imply the same for video learning as postgraduate students are definitely more experienced and therefore they can watch and understand longer video clips.

\section{Conclusion And Suggestions}

All in all, it's clear that students perceive the benefits of learning through video clips especially in understanding and enriches the teaching topic and even makes the topic more interesting. The overall finding is definitely consistent with previous research by López, Ferrando and Fabregat-Sanjuan (2016), Kay (2012), Ljubojevic et al. (2014) as well as Hsin \& Cigas (2013) that using videos in teaching does improve students' learning capability. 
As suggested by Brame (2016), videos and clips need to display key information and be divided into smaller parts and this may improve learning using video clips, as shown in Table 3, students agree on these two improvements. Similarly, most students also agree that the elimination of extra irrelevant information in video is a good thing. Besides, they agree that the right audio and visual channels are good for video learning, and that videos can be more effective when played in the middle of the class. In addition, teachers' involvement in controlling the video will make the video teaching more meaningful as they can pause, ask questions and even replay key segments of the videos and clips (Bell \& Bull, 2010).

A simple comparison between postgraduate and undergraduate students' perceptions towards the learning effectiveness and improvements is also conducted in which they are indifferent in most variables. However, undergraduate students seem to prefer segmenting the video clips into smaller parts and videos playing during middle session of a class. This is comparable to studies of Illovsky's (2010) and Peixoto et al. (2012) that postgraduate students are more endurable and hardworking if compared to undergraduate students since most postgraduate students only perceive moderately about these two variables.

However, this research did not include performance as a dependent variable for measuring video learning effectiveness. Perhaps this can be used in the future for measuring video learning effectiveness. And the sample size can be further increased to give more thorough views of learning effectiveness through video clips. Besides, other comparison studies such as comparison between genders, degree programmes or age groups maybe conducted to measure and compare the learning effectiveness of video learning among groups.

\section{References}

Adams, D., Sumintono, B., Mohamed, A., \& Mohamad Noor, N.S. (2018). E-Learning Readiness Among Students Of Diverse Backgrounds In A Leading Malaysian Higher Education Institution. Malaysian Journal of Learning and Instruction, 15 (2), 227-256. Retrieved from http://mjli.uum.edu.my/images/vol.15no.2/227-256new.pdf

Beheshti, M., Taspolat, A., Kaya, S.O. \& Sapanca, F. H. (2018). Characteristics of instructional videos. World Journal on Educational Technology: Current Issues, 10(1), 061-069. Retrieved from https://files.eric.ed.gov/fulltext/EJ1170366.pdf

Bell, L., \& Bull, G. (2010). Digital video and teaching. Contemporary Issues in Technology and Teacher Education, 10(1), 1-6. Retrieved from https://citejournal.org/wpcontent/uploads/2016/04/v10i1editorial1.pdf

Brame, C.J. (2016). Effective educational videos: Principles and Guidelines for Maximizing Student Learning from Video Content. CBE-Life Sciences Education, 15(4), 1-6. doi: 10.1187/cbe.16-03-0125

Brecht, H. D., \& Ogilby, S. M. (2008). Enabling a comprehensive teaching strategy: Video lectures. Journal of Information Technology Education: Innovations in Practice, 7(2008), 71-86. Retrieved from http://www.jite.org/documents/Vol7/JITEV7IIP071086Brecht371.pdf

Brecht, H.D. (2012). Learning from Online Video Lectures. Journal of Information Technology Education: Innovations in Practice, 11(2012). 227-250. Retrieved from http://www.jite.informingscience.org/documents/Vol11/JITEv11IIPp227250Brecht1091.pdf

Conway, K. (2011). How Prepared Are Students for Postgraduate Study? A Comparison of the Information Literacy Skills of Commencing Undergraduate and Postgraduate 
Information Studies Students at Curtin University. Australian Academic \& Research Libraries, 42(2), 121-135. doi: 10.1080/00048623.2011.10722218

Copley, J. (2007). Audio and video podcasts of lectures for campus-based students: Production and evaluation of student use. Innovations in Education and Teaching International, 44(4), 387-399. doi:10.1080/14703290701602805

Geri, N. (2012). The resonance factor: Probing the impact of video on student retention in distance learning. Interdisciplinary Journal of E-Learning and Learning Objects, 8 (2012), 1-13. Retrieved from http://www.ijello.org/Volume8/IJELLOv8p001013Geri0794.pdf

Hsin, W. J., \& Cigas, J. (2013). Short videos improve student learning in online education. Journal of Computing Sciences in Colleges, 28(5), 253-259. Retrieved from $\mathrm{http} / / /$ kauppinen.net/tomi/learning-in-the-era-of-online-videos-camera-ready.pdf

Illovsky, M.E. (2012). Psychological Comparisons of Undergraduate and Graduate College of Education Students. International Journal of Teaching and Learning in Higher $\begin{array}{lllll}\text { Education, } & 22 & \text { (3), } & 238-245 . & \text { Retrieved from }\end{array}$ https://files.eric.ed.gov/fulltext/EJ938559.pdf

Kay, R.H. (2012). Exploring the use of videopodcasts in education: A comprehensive reviewof the literature. Computers in Human Behavior, 28(2012), 820-831. Retrieved from https://www.lth.se/fileadmin/cee/Documents/Kay_2012_Podcasts.pdf

Lau, K.P., Chiu, D.K.W., Ho, K.K.W., Lo, P., \& See-To, E.W.K. (2017). Educational Usage of Mobile Devices: Differences Between Postgraduate and Undergraduate Students.

The Journal of Academic Librarianship, 43(3), 201-208. doi: 10.1016/j.acalib.2017.03.004

Ljubojevic, M., Vaskovic, V., Stankovic, S., \& Vaskovic, J. (2014). Using Supplementary Video in Multimedia Instruction as a Teaching Tool to Increase Efficiency of Learning and Quality of Experience. International Review of Research in Open and Distance Learning, 15(3), 276-291.Retrieved from https://files.eric.ed.gov/fulltext/EJ1033049.pdf

López, S.D.F., Ferrando, F., \& Fabregat-Sanjuan, A. (2016). Learning/training video clips: an efficient tool for improving learning outcomes in Mechanical Engineering. International Journal of Educational Technology in Higher Education, 13(6), 1-13. doi:10.1186/s41239-016-0011-4

Peixoto, H.M., Peixoto, M.M., \& Alves, E.D. (2012). Learning strategies used by undergraduate and postgraduate students in hybrid courses in the area of health. Rev. Latino-Am. Enfermagem, 20(3). doi:10.1590/S0104-11692012000300017

Sekaran, U., \& Bougie, R. (2016). Research Methods For Business: A Skill Building Approach. West Sussex, United Kingdom: John Wiley \& Sons.

Whatley, J., \& Ahmad, A. (2007). Using video to record summary lectures to aid students' revision. Interdisciplinary Journal of E-Learning and Learning Objects, 3(2007), 185196. Retrieved from http://www.ijklo.org/Volume3/IJKLOv3p185196Whatley367.pdf

Zhang, D., Zhou, L., Briggs, R.O., \& Nunamaker, J.F. (2006). Instructional video in elearning: Assessing the impact of interactive video on learning effectiveness. Information \& Management, 43(1), 15-27. doi:10.1016/j.im.2005.01.004 